\title{
Leptoconops nosopheris sp. n. (Diptera: Ceratopogonidae) and Paleotrypanosoma burmanicus gen. n., sp. n. (Kinetoplastida: Trypanosomatidae), a biting midge - trypanosome vector association from the Early Cretaceous
}

\author{
George Poinar Jr. \\ Department of Zoology, Oregon State University, Corvallis, OR 97331, USA
}

Leptoconops nosopheris $s p$. $n$. (Diptera: Ceratopogonidae) is described from a blood-filled female biting midge in Early Cretaceous Burmese amber. The new species is characterized by a very elongate terminal flagellomere, elongate cerci, and an indistinct spur on the metatibia. This biting midge contained digenetic trypanosomes (Kinetoplastida: Trypanosomatidae) in its alimentary tract and salivary glands. These trypanosomes are described as Paleotrypanosoma burmanicus gen. $n$., $s p$. $n$., which represents the first fossil record of a Trypanosoma generic lineage.

Key words: Cretaceous - biting midge - trypanosomatids - fossil

The fossil record of trypanosomatids is limited to Paleoleishmania proterus Poinar and Poinar (2004) vectored by an Early Cretaceous sand fly in Burmese amber and Trypanosoma antiquus Poinar vectored by a triatomid bug in Tertiary Dominican amber (Poinar 2005). The present study reports a novel association between a new species of biting midge belonging to the genus Leptoconops (Diptera: Ceratopogonidae) and a new species of associated trypanosome in Cretaceous Burmese amber. The trypanosomes were located in the gut, salivary glands and salivary secretions of the biting midge.

The amber was derived from a mine first excavated in 2001, in the Hukawng Valley, Southwest of Maingkhwan in the state of Kachin $\left(26^{\circ} 20^{\prime} \mathrm{N}, 9^{\circ} 36^{\prime} \mathrm{E}\right)$ in Burma, (Myanmar). This new amber site, known as the Noije Bum 2001 Summit Site, was assigned to the Upper Albian of the Early Cretaceous on the basis of paleontological evidence (Cruickshank \& Ko 2003), placing the age at 97 to 110 m.y.a. Nuclear magnetic resonance spectra and the presence of araucaroid wood fibers in amber samples from the Noije Bum 2001 Summit site indicate an araucarian (possibly Agathis) tree source for the amber (Poinar et al. 2007).

\section{MATERIALS AND METHODS}

The amber piece containing the fossil biting midge with its associated trypanosomes was first shaped with a Lortone Model FS Lapidary Trim saw, then sanded on a Highland Park 1009 sander and finally polished on a Black and Decker 5 inch model 7900 bench grinder, during which time the specimen was observed with a Nikon

E-mail: poinarg@science.oregonstate.edu

Received 20 February 2008

Accepted 21 July 2008
SMZ-10 R stereoscopic microscope. The final piece is roughly rectangular in outline, measuring $12 \mathrm{~mm}$ long by $7 \mathrm{~mm}$ wide and $1 \mathrm{~mm}$ in depth. The flagellates were observed and photographed with a Nikon Optiphot compound microscope with magnifications up to $1,050 \mathrm{X}$.

The insect's tissues had partially cleared (Fig.1), thus allowing an unobstructed view of the alimentary tract, body cavity and salivary glands. The flagellates were preserved by natural fixatives in the original plant resin, which enter the cells soon after contact is made with the deposit. The method of insect preservation in resins is discussed by Poinar and Hess $(1982,1985)$. With this natural fixation process, most flagellates appear as opaque or translucent outlines under transmitted light. When visible, nuclei appear as large dark objects, while kinetoplasts are represented as small dark objects. The undulating membranes can be detected as wavy, transparent zones located along the side of the flagellates. It is difficult to photograph such small microbes through both the amber matrix and insect's body wall and the images are not as clear as extant forms are on a microscope slide. The images of the trypanosomes were enhanced in Adobe Photoshop by manipulating the brightness, contrast and magnification.

\section{Leptoconops nosopheris sp. n. (Figs. 1-3)}

Female - (Fig. 1) Body length $1.2 \mathrm{~mm}$; antenna (Fig. 3) with 12 flagellomeres; length antenna, $322 \mu \mathrm{m}$; flagellomeres nearly spherical in shape, slightly longer than wide; flagellomere 12 narrow, $82 \mu \mathrm{m}$ long; 2.9 times as long as flagellomere 10 (flagellomere 11 is slightly compressed) (Fig. 3); proboscis relatively long; palp four-segmented with third palpomere wider than others; eye separation not visible; hind tibia with indistinct apical spur; claws small, simple; wing length, $626 \mu \mathrm{m}$; costa slightly prolonged beyond vein R3; membrane covered with distinct microtrichia; macrotrichia absent; $\mathrm{CR}=0.20$; abdomen slender; cerci very long, $206 \mu \mathrm{m}$, 4.1 times as long as wide at the widest portion (Fig. 2). 


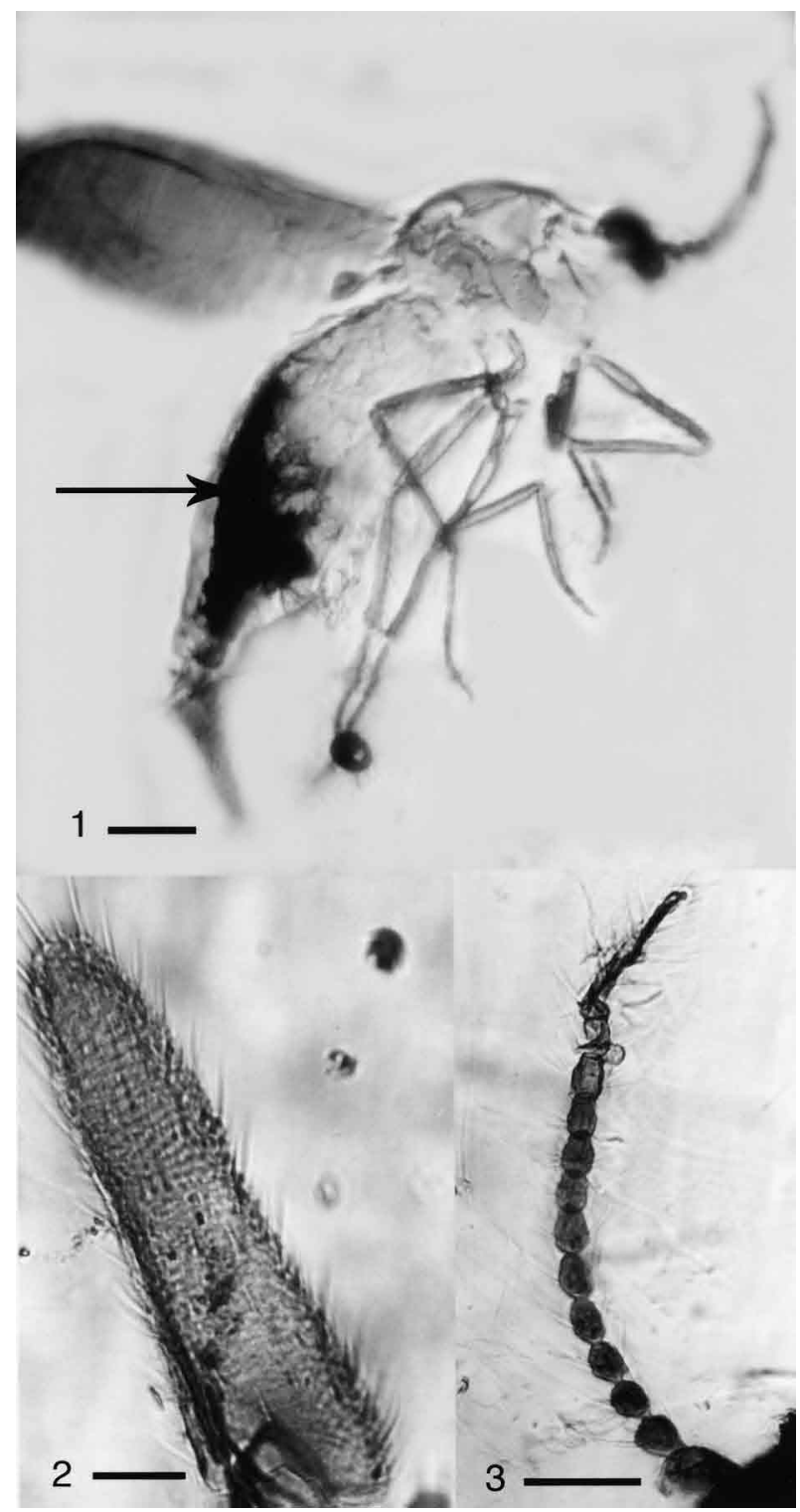

Figs. 1-3: Leptoconops nosopheris sp. n., holotype female. 1: body. Arrow shows partially digested blood meal. $\mathrm{Bar}=130 \mu \mathrm{m} ; 2$ : elongate cerci. Bar $=28 \mu \mathrm{m}$. 3: antenna. $\mathrm{Bar}=63 \mu \mathrm{m}$.

Male - unknown.

Type locality - Amber mine in the Hukawng Valley, Southwest of Maingkhwan in the state of Kachin $\left(26^{\circ} 20^{\prime} \mathrm{N}, 96^{\circ} 36^{\prime} \mathrm{E}\right)$, Northern Myanmar (Burma).

Type material - Holotype female in Burmese amber piece, deposited in the Poinar amber collection (code BD-47b) maintained at Oregon State University, USA.

Etymology - Noso is from the Greek for disease, sickness and pheris is from the Greek phero, to carry or bear.

The biting midge had the remains of a blood meal associated with masses of trypanosomes in its midgut. The peritrophic membrane was no longer evident and most of the trypanosomes were distributed along the outer edge of the remaining brownish-yellow residue. No try- panosomes could be seen in the hemocoel, but they were quite abundant in the salivary glands and salivary ducts and some had been expelled from the tip of the insect's proboscis in a droplet of salivary secretion.

All of the forms were relatively slender, which may have been due to shrinkage during the fossilization process in the amber. While it was difficult to see the position of the kinetoplast in relation to the nucleus in most specimens, some had the orientation of the nuclei and kinetoplasts characteristic of trypomastigotes and epimastigotes, as well as undulating membranes along the border of their bodies.

\section{Paleotrypanosoma gen. $\mathrm{n}$.}

General diagnosis: Trypanosomatine: Trypanosomatidae. Paleotrypanosoma gen. $\mathrm{n}$. is established for fossil members of the generic lineage Trypanosoma associated with extinct species of biting insects. The remarkable diagnostic characters of Paleotrypanosoma gen. $\mathrm{n}$. are its age, presence of slender stages, absence of amastigotes and occurrence in an extinct species of biting midge.

\section{Paleotrypanosoma burmanicus sp. n. (Figs. 4- 9)}

The description is based on epimastigotes and trypomastigotes located along the edge of the blood residue in the gut (Fig. 1) and in the salivary droplet issuing from the proboscis of the biting midge (Fig. 9).
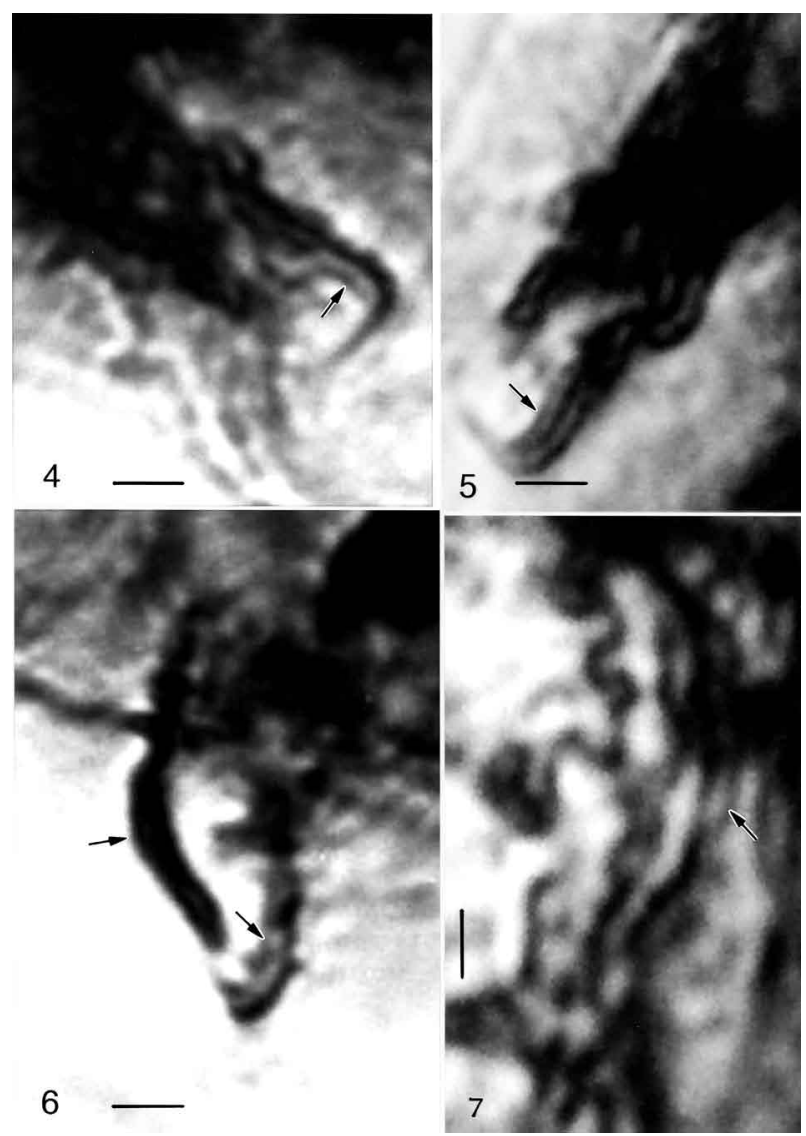

Figs. 4-7: Paleotrypanosoma burmanicus sp. $\mathrm{n}$. Stages with undulating membrane (arrow). Bars $=2.3 \mu \mathrm{m} ; 2.4 \mu \mathrm{m} ; 2 \mu \mathrm{m}$ and $2 \mu \mathrm{m}$, respectively. 


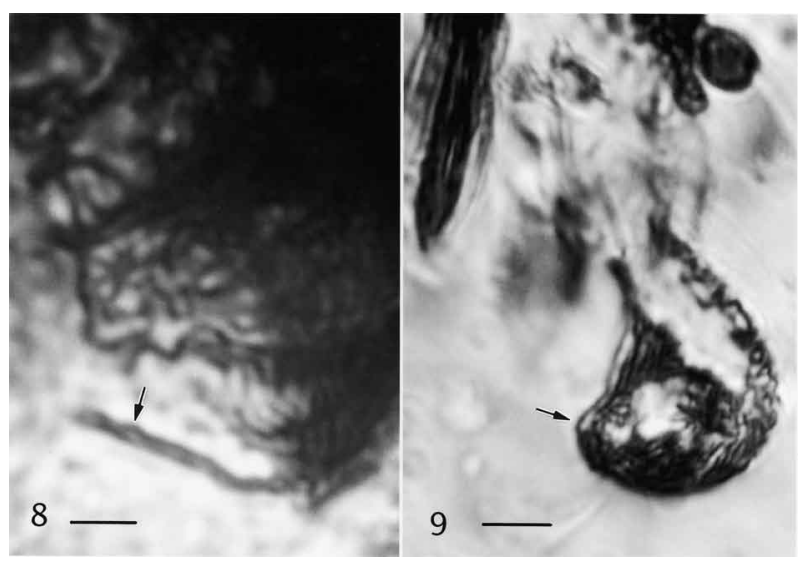

Figs. 8-9: Paleotrypanosoma burmanicus sp. n. 8: stage with undulating membrane (arrow). Bar $=2.4 \mu \mathrm{m}$. 9: trypanosomatids in salivary secretion (arrow) extruded from proboscis of Leptoconops nosopheris sp. n. $\operatorname{Bar}=10 \mu \mathrm{m}$.

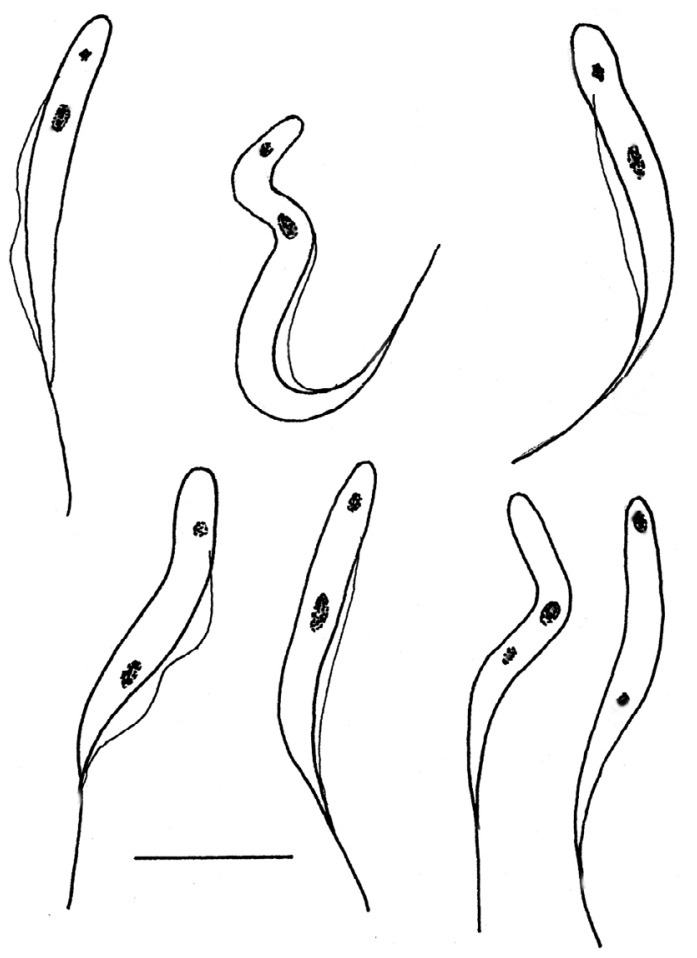

Fig. 10: various stages of Paleotrypanosoma burmanicus $\mathrm{sp}$. n. noted in the midgut and salivary secretions of Leptoconops nosopheris sp. $\mathrm{n}$. All except the two on the right in the lower row are considered to be trypomastigotes. The two on the right in the lower row are considered to be epimastigotes. $\mathrm{Bar}=4 \mu \mathrm{m}$.

Trypanosomes $(\mathrm{n}=15)$ - Average length $=12 \mu \mathrm{m}$, range $=9-15 \mu \mathrm{m}$; average width $=1.8 \mu \mathrm{m}$, range $=1.3-$ $2.0 \mu \mathrm{m}$; average length of flagellum $=6 \mu \mathrm{m}$, range $=5-7$ $\mu \mathrm{m}$. Some variation was noted regarding the positions of the kinetoplast and nuclei. Trypanosomes with the kinetoplast in the posterior portion of the body were regarded as trypomastigotes while those with the kinetoplast anterior to the nucleus were considered epimastigotes.
Type material - Trypomastigote in the gut of L. nosopheris s. $\mathrm{n}$. in Burmese amber deposited in the Poinar amber collection (code B-D-47b) maintained at Oregon State University, USA.

Type host: L. nosopheris sp. n. (Diptera: Ceratopogonidae) in Burmese amber; vertebrate host unknown.

Type locality - Amber mine in the Hukawng Valley, southwest of Maingkhwan in the state of Kachin $\left(26^{\circ} 20^{\prime} \mathrm{N}, 96^{\circ} 36^{\prime} \mathrm{E}\right)$, Northern Myanmar (Burma).

Etymology - The specific name of this protozoan species refers to country where is located its type locality, Burma.

\section{DISCUSSION}

Females of the genus Leptoconops feed on vertebrate blood from reptiles, birds and mammals (Auezova et al. 1990, Mullens et al. 1997, Mullen 2002, Szadziewski \& Poinar 2005). The genus extends back some 130 million years with species found in Lebanese amber (Poinar \& Milki 2001). There are 134 extant and, with the present specimen, 14 fossil species, five of which occur in Burmese amber (Szadziewski \& Poinar 2005). This is the first species of Leptoconops, extant or extinct, associated with trypanosomes.

Both digenetic and monogenetic trypanosomes have been reported from extant biting midges (Sharp 1928, Kremer et al. 1961, Baker 1976, Podlipaev et al. 2004b, Svobodová et al. 2007) and a monogenetic species is known from a biting midge in Burmese amber (Poinar $\&$ Poinar 2005). One extant trypanosome isolated from a biting midge was closely related to a strain isolated from Egyptian rats and could have been transferred to the vertebrate by the insect during blood feeding (Podlipaev et al. 2004a).

Since biting midges take blood from all classes of vertebrates, it is not possible to determine the host of $P$. burmanicus $\mathrm{sp}$. n. Many workers implicate biting midges (together with black flies and mosquitoes) as carriers of bird trypanosomes with transmission through contamination or ingestion of the vector (posterior station transmission) (Bennett 1961, 1970, Desser et al. 1975, Baker 1976, Miltgen \& Landau 1982, Votypka \& Svobodová 2004). However metacyclic trypomastigotes were noted in the mouth parts and salivary glands of some of the vectors and inoculative experiments showed that these forms were infective (Bennett 1970, Baker 1976).

Since epimastigotes and trypomastigotes were found in the alimentary tract, salivary glands and salivary secretions of L. nosopheris sp. n., P. burmanicus sp. n. is considered to be a digenetic trypanosome that is transmitted by the bite of the biting midge. The life cycle of $P$. burmanicus $\mathrm{sp} . \mathrm{n}$. is probably similar to that of Trypanosoma b. brucei in the tsetse fly, Glossina m. morsitans. In the tsetse fly, the trypanosomes first multiply in the midgut, then migrate anteriorly to the foregut and finally into the salivary glands. Vertebrate-infective trypanosomes also occurred in salivary exudates which were extruded by the infected tsetse flies (Peacock et al. 2007). 
All studied biting midge- transmitted trypanosomes that infect birds are carried by species of the genus $\mathrm{Cu}$ licoides Latreille (Fallis \& Bennett 1961, Bennett 1961, 1970, Baker 1976, Miltgen \& Landau 1982, Linley 1985). However it has been speculated that present day bird trypanosomes evolved from species that parasitized reptiles (Baker 1976), so it is possible that P. burmanicus sp. n. was parasitizing reptiles 100 million years ago. Support for a reptilian host are studies showing that several extant species of Leptoconops feed on lizards (Auezova et al. 1990, Mullens et al. 1997) and tortoises (Moravec \& Orszagh 1998, Široký et al. 2007).

There is evidence that vertebrate parasitism by trypanosomatids evolved multiple times in the past (Fernandes et al. 1993) and that the earliest trypanosomatid lineage was T. brucei. While this species is vectored by tsetse flies today, it is possible that in the Early Cretaceous, before tsetse flies evolved, precursors of the $T$. brucei or a now extinct lineage were being vectored by biting midges. It is possible that biting midges were the original ancestral vectors of the Trypanosoma lineage, since vertebrate feeding ceratopogonids extend back some 130 million years (Poinar \& Milki 2001). Later, these flagellates could have been acquired by other biting Diptera, which acted as bridge vectors and transferred the parasites to new vertebrate hosts.

\section{ACKNOWLEDGMENTS}

To RL Jacobson, for providing references and discussions during the course of this study, and Roberta Poinar for comments on earlier versions of the manuscript.

\section{REFERENCES}

Auezova G, Brushko Z, Kubykin R 1990. Feeding of biting midges (Leptoconopidae) on reptiles. Abst. 2nd Internat. Congress Dipterology, Bratislava, Czechoslovakia, p. 12.

Baker JR 1976. Biology of the Trypanosomes of birds. In WHR Lumsden, DA Evans (eds.), Biology of the Kinetoplastida, Vol. 1, Academic Press, New York, p. 131-174.

Bennett GF 1961. On the specificity and transmission of some avian trypanosomes. Can J Zool 39: 17-33.

Bennett GF 1970. Development of trypanosomes of the T. avium complex in the invertebrate host. Can J Zool 48: 945-957.

Cruickshank RD, Ko K 2003. Geology of an amber locality in the Hukawng Valley, northern Myanmar. J Asian Earth Sci 21: 441-455.

Desser SS, McIver SB, Jez D 1975. Observations on the role of simuliids and culicids in the transmission of avian and anurian trypanosomes. Int J Parasitol 5: 507-509.

Fallis AM, Bennett GF 1961. Ceratopogonidae as intermediated hosts for Haemoproteus and other parasites. Mosq News 21: 21-28.

Fernandes AP, Nelson K, Beverley SM 1993. Evolution of nuclear ribosomal RNAs in kinetoplastid protozoa: Perspectives on the age and origins of parasitism. Proc Natl Acad Sci 90: 11608-11612.

Kremer M, Vermeil C, Callot J 1961. Sur quelques nematoceres vulnerants des eaux salées continentals de l'est de la France. Bull Assoc Philomath d'Alsace et de Lorraine 11: 1-7.

Linley JR 1985. Biting midges (Diptera:Ceratopogonidae) as vectors of nonviral animal pathogens. J Med Entomol 22: 589-599.

Miltgen F, Landau I 1982. Culicoides nubeculosus, vecteur expéri- mental d'un nouveau trypanosome de Psittaciforme: Trypanosoma bakeri n. sp. Ann Parasitol Hum Comp 57: 423-428.

Moravec J, Orszagh I 1998. Testudo graeca terrestris als Wirt von Leptoconops irritans (Diptera: Ceratopogonidae). Salamandra 34: 181-182.

Mullen GR 2002. Biting midges (Ceratopogonidae). In G Mullen, L Durden (eds.), Medical and Veterinary Entomology, Academic Press, New York, p. 163-183.

Mullens BA, Barrows C, Borkent A 1997. Lizard feeding by Leptoconops (Brachyconops) californiensis (Diptera: Ceratopogonidae) on desert sand dunes. J Med Entomol 34: 735-737.

Peacock L, Ferris V, Bailey M, Gibson W 2007. Dynamics of infection and competition between two strains of Trypanosoma brucei brucei in the tsetse fly observed using fluorescent markers. Kinetoplastid Biol Dis 6: 1-4.

Podlipaev SA, Sturm NR, Fiala I, Fernandes O, Westenberger SJ, Dollet M, Campbell DA, Lukes J 2004a. Diversity of insect trypanosomatids assessed from the Spliced Leader RNA and 5S rRNA Genes and Intergenic Regions. J Eukary Microbiol 51: 283-290.

Podlipaev SA, Votypka J, Jirku M, Svobodova M, Ljkes J 2004b. Herpetomonas ztiplinka $\mathrm{n}$. sp. (Kinetoplastida: Trypanosomatidae): a parasite of the blood-sucking biting midge Culicoides kibunensis Tokunaga, 1937 (Diptera: Ceratopogonidae). J Parasitol 90: 342-347.

Poinar Jr GO 2005. Triatoma dominicana sp. n. (Hemiptera: Reduviidae: Triatominae), and Trypanosoma antiquus sp. n. (Stercoraria: Trypanosomatidae), the first fossil evidence of a TriatomineTrypanosomatid vector association. Vector Borne Zoonotic Dis 5: $72-81$.

Poinar Jr GO, Hess R 1982. Ultrastructure of 40-million-year-old insect tissue. Science 215: 1241-1242.

Poinar Jr GO, Hess R 1985. Preservative qualities of recent and fossil resins: Electron micrograph studies on tissues preserved in Baltic amber. J Baltic Studies 16: 222-230.

Poinar Jr G, Lambert JB, Wu Y 2007. Araucarian source of fossiliferous Burmeses amber: spectroscopic and anatomical evidence. $J$ Bot Res Inst Texas 1: 449-455.

Poinar Jr GO, Milki R 2001. Lebanese amber. Oregon State University Press, Corvallis, $96 \mathrm{pp}$.

Poinar Jr GO, Poinar R 2004. Paleoleishmania proterus n. gen., n. sp., (Trypanosomatidae: Kinetoplastida) from Cretaceous Burmese amber. Protista 155: 305-310.

Poinar Jr GO, Poinar R 2005. Fossil evidence of insect pathogens. $J$ Invertebr Pathol 89: 243-250.

Sharp NAD 1928. Filaria perstans: its development in Culicoides austeni. Trans R Soc Trop Med Hyg 21: 371-396.

Široký P, Jandzík D,Mikulíček P, Moravec J, Országh I 2007. Leptoconops bezzi (Diptera: Ceratopogonidae) parasitizing tortoises Testudo graeca (Testudines: Testudinidae) in mountain ranges of Lebanon and western Syra. Parasitol Res 101: 485-489.

Svobodová M, Zidková L, Cepicka I, Obornik M, Lukes J, Votypka J 2007. Sergia podlipaevi gen. nov., sp. nov. (Trypanosomatidae, Kinetoplastida), a parasite of biting midges (Ceratopogonidae, Diptera). Int J Syst Evol Microbiol 57: 423-432.

Szadziewski R 2004. Biting midges (Diptera: Ceratopogonidae) from Burmese amber, Myanmar. J Syst Palaeontol 2: 115-121.

Szadziewski R, Poinar Jr GO 2005. Additional biting midges (Diptera:Ceratopogonidae) from Burmese amber. Polska Pismo Entomol 74: 349-362.

Votypka J, Svobodová M 2004. Trypanosoma avium: experimental transmission from black flies to canaries. Parasitol Res 92: 147-151. 